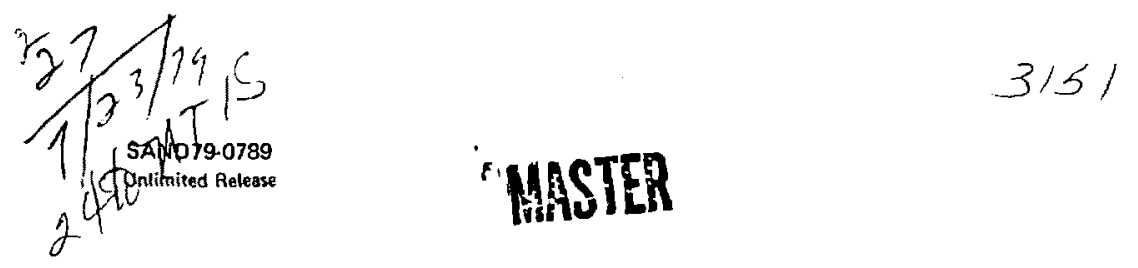

\title{
Borehole Plugging Program Plugging of ERDA No. 10 Drill Hole
}

Charles W. Gulick, Jr

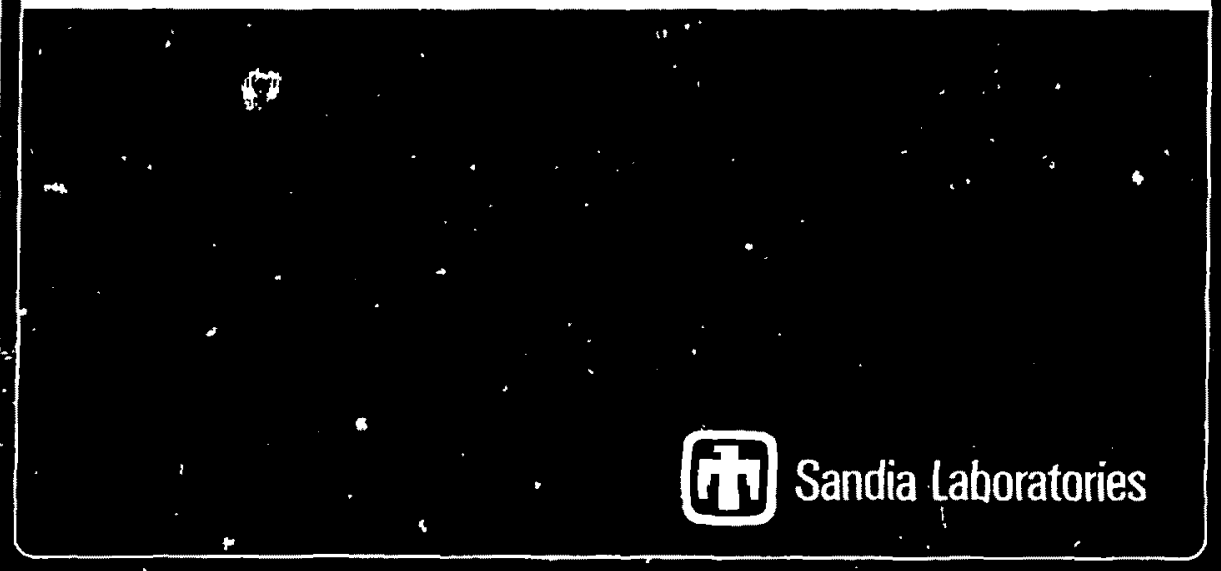




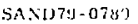

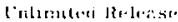

l'risted Iuste 10?

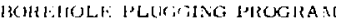

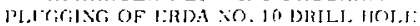

Charles Min Cinlect, ir

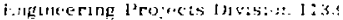

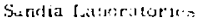

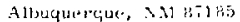

\section{A BST'R:'}

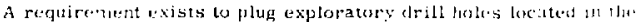

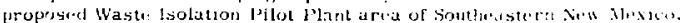

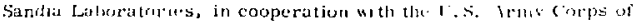

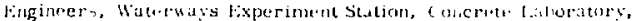

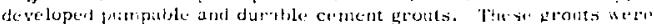

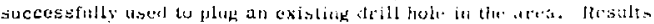

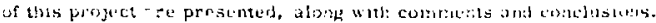

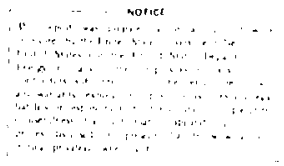


I'he plugging operationg for the ERDA No. $10 \mathrm{Jrill}$ hole were closely supervised by D. M. Walley of the Grouting Branch of the Concrete Laboratory of the U.S. Army Engineer Waterway 3 Experiment Station, Vicksburg, Mississippi. R. A. Bendinelli, head of the Grouting Branch, actively participated in the coordination meetings and preparation for the field activities. W. F:. Cunningham of Fenix \& Scisson was in charge of the field activities for the drilling and plugging of the exploratory drill hole. The cementing contractor for the plugging operations was the Dowell Division of the Dow Chemical Company. The preparatory testing aud development work For the specific plug mixture designs was accomplished at Dowell's Midland, Texas Division Laboratory under the direction of E, L, Shumaker, Regional Engineering Manager. All of the participating agencies were yery responsive to the dield needs, and the sucess 15 due to the sooperation of the above personnel and their field and iab crews. 
Introduction

Hole History

Plugging Plan

Pluggang Operations

Plup 1

Plug 2

Plug 3

Plug 4

General Comments and Conclusions $\underline{\text { Page }}$

7

i

9

17

17

19

21

21

22

\section{IL LUSTIRATKONS}

Figure

1 ERUA Nus 10 Brill Jus.

2 Culiprer Log
13

11 
BOREHOLE PLUGGING PROGRAM

PLUGGING OF ERDA NO. 10 DRILL HOLE,

Introduction

Sandia Laboratories has been sponsoring the development of pumpable and durable cement grouts for use in the Borehole Plugging Program in support of the nuclear Waste Isolation Pilot Plant (WIPP). Reference 1 discusses the background and first year's results of the studies at the Concrete Laboratory of the U.S. Army Engineer Waterways Experi ment Station (WES), Vicksburg, Mississippi.

In 1977 the decision to plug exploratory drill hole ERDA No. 10 near the WIPP site in southeastern New Mexico provided an opportunity to initiate a quality control and quality assurance program for hole plugging under field conditions. The entire batching and mixing operationg were under the close superviston of personnel from the Grouting Branch of Wies.

Hole, History

A permit to drill ERDA No, 10 was requested in early August 1977 and approved. The hole is located in S34. T23S, R30E in Eddy County, New Mexico, $2327 \mathrm{ft}$ from east line and 200 ft from north line. The location is about 15 miles east of Loving. New Mexico, near the project Gnome site. Ground level (GL) is $3371 \mathrm{ft}$.

Excavation of the $6 \times 6 \times 6 \mathrm{ft}$ cellar was initiated on August 11 . An 18 -in. diameter hole was drilled from ground level to $40 \mathrm{ft}$, and an 13-3/8 in. $-O D$ casing was set at $37 \mathrm{ft}$. The annulus was cemented to the cellar noor with $81 \mathrm{ft}^{3}$ of Class A cement. Mobilization of the drilling rig was completed in place on August 18. All depths in she hole are from the Kelly bushing which was 13 it above ground level.

The intial hole diameter for the suriace casing was $7-7 / 8 \mathrm{in.}$ It was then opened to $12-1 / 4$ in. to the depth of $805 \mathrm{ft}$. A nitroger pocket at 675 it unloaded the mud from the hole while making a connection in the dril string. The casing ID was $9.92 \mathrm{in}$. and was get from g05 $\mathrm{ft}$ to GL. The annulus was cemented on August 21 with $508 \mathrm{ft}^{3}$ of Class C cement with $2 \%$ calcium chioride by Dowell. The top of the cement subsided to a 51 -ft depth. A second stage was placed by using $46 \mathrm{dt}^{3}$ of the eame mix and circulating $13 \mathrm{ft}^{3}$ out of the annulus. 
The cement surface inside the casing was tagged at $760 \mathrm{ft}$. The cement and shue were drilled out. and the hole was rotary drilled to $2095 \mathrm{ft}$ with a $7-7 / 8 \mathrm{in}$. bit. Cores were cut to $3+00 \mathrm{ft}$ by using a G0-It long core barrel with a 7-13/IG $\times 4-1 / 4 \mathrm{in}$. core bit. The battom $120 \mathrm{ft}$ was reamed and drilled to $3406 \mathrm{ft}$. Birdwell logs were run on September 9, and drill stem testing was completed on September 15.

The hole was rotary drilled to a depth of $3815 \mathrm{ft}$. Three cores were cut through the interval of 3815 to $3927 \mathrm{ft}$. The USGS logs were run an September 18, and drill stem testing was completed on September 20. Rotary drilling then deepened the hole to $4330 \mathrm{ft}$, and wo cores were cut to the Lotal depth (TD) of $4431 \mathrm{ft}$ in the Bell Canyon formation. Schlumberger ionic logs ard LSGS logs wert completed on September 26. Drill stem testing was completed on September 30, and the hole was conditioned and ready for plugging on Septernber 30. I 4 gure I shows the plugging plan, locations of drilling and coring, and approximate depths for the major geologic features.

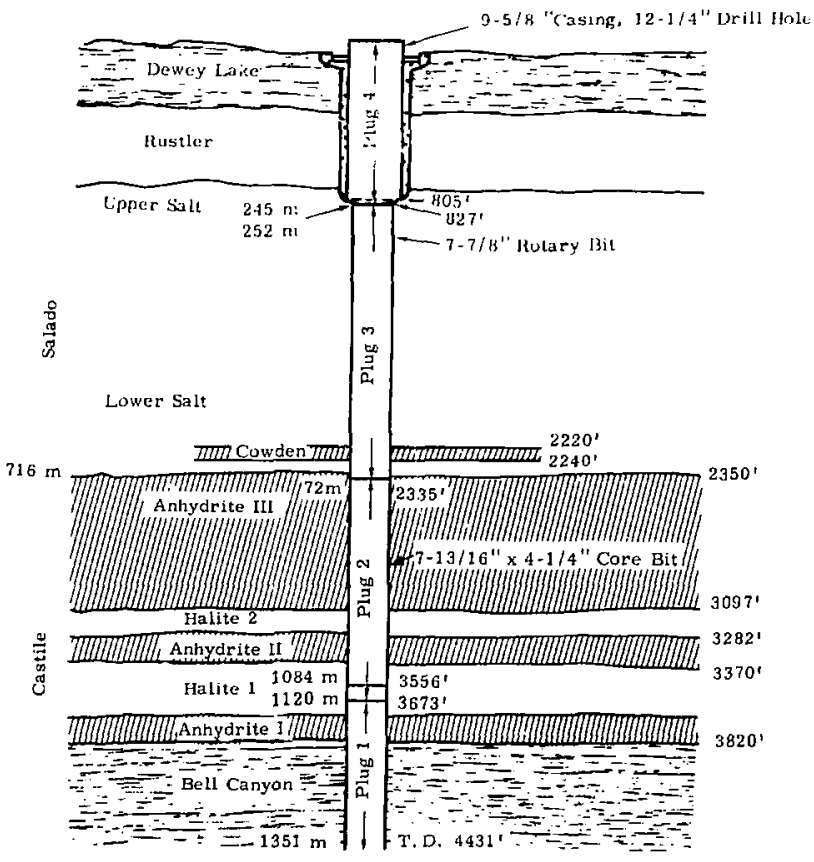

Figure 1. ERDA No. 10 Drill Hole 
Preliminary mectings were held with two potential grouting contractors in Carlsbad an September 7-8. Sandia representatives from Divigion 1133 and Department 5310, Fenix \& Scisson and WES participated in both meetings. The proposed plugging plan in Fig.se 1 listed four plugs as follows:

$\begin{array}{ccc}\text { Plug No. } & \frac{\text { Depth }(f t)}{4431-3730} & \frac{\text { Length }(\mathrm{ft})}{701} \\ 1 & 3730-2300 & 1430 \\ 3 & 2300-800 & 1500 \\ 4 & 800-G L & 800\end{array}$

These depths were intended to place the first plug from total depth up to a short distance into the castile formation. The second and third plugs were intended to divide the distance through the salt section up to the bottom of the casing appr ximately is half. This would reduce formation damage from the pressure head of the fluid grout, 'Ithe fourth plug filled the inside of the casing to ground level. Dowell was chosen to accomplish the pligging operations.

Dowell and Fenix \& Scisson pesonel held several mectings between suptember y and 30 to review the caljper logs from the hole, to detarmine the quantity for eich plug, and to review the lab data from the Dowell Midland Laboratory for each of the mixture destgns cured under press:res and temperature simulating the field conditions for each plug. Figure 2 is the caliper log for the hole which was used for determining the volume of each plug. An excess volume of $30 \%$ was used for plugs 1, 2, and 3. Inside the casing for plug 4 the excess vas 20\%. The following volumes were determined for each of the plugs:

\begin{tabular}{|c|c|c|c|}
\hline Plug No. & $\begin{array}{l}\text { Measured Volume } \\
\left(\mathrm{ft}^{3}\right) \\
\end{array}$ & 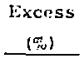 & $\begin{array}{l}\text { Total Volume } \\
\left(\mathrm{ft}^{3}\right) \\
\end{array}$ \\
\hline 1 & 319 & 30 & 114 \\
\hline 2 & 800 & 30 & 1040 \\
\hline 3 & 1023 & 30 & 1330 \\
\hline 4 & 347 & 20 & 417 \\
\hline
\end{tabular}




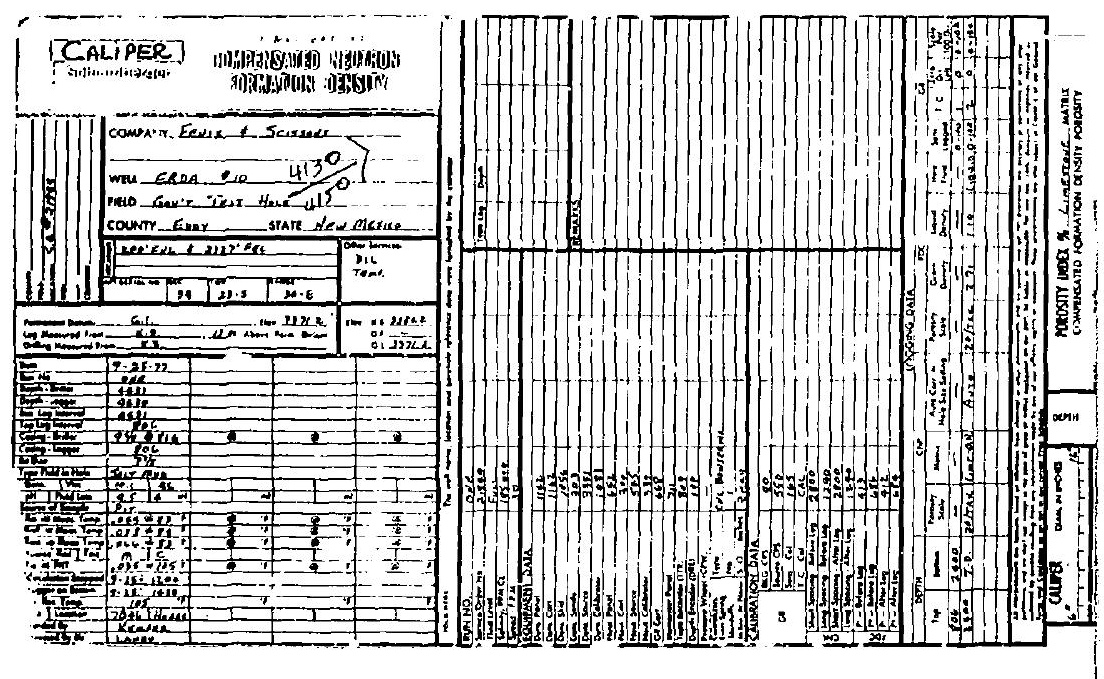

Figure 2. Calip 


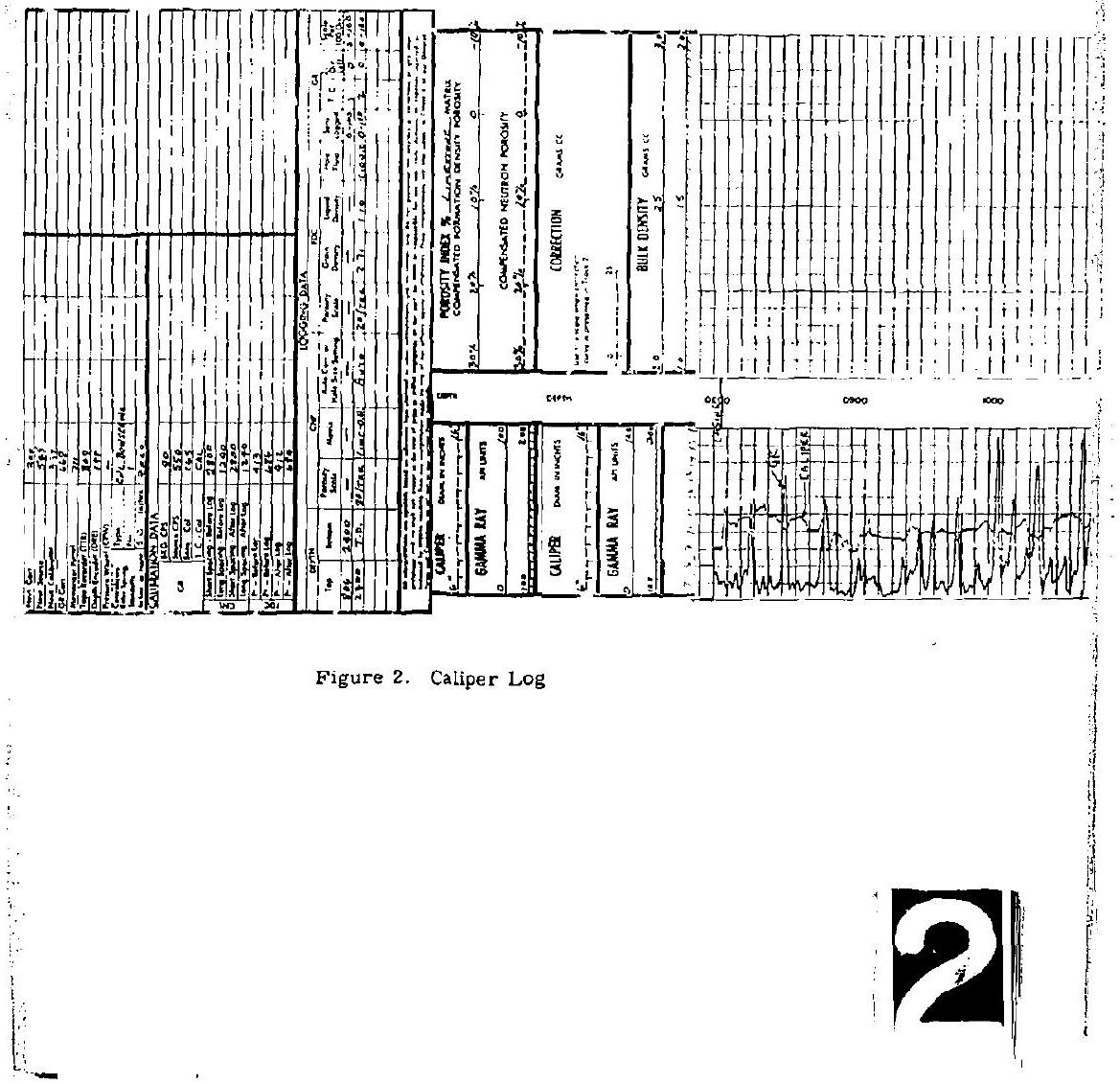




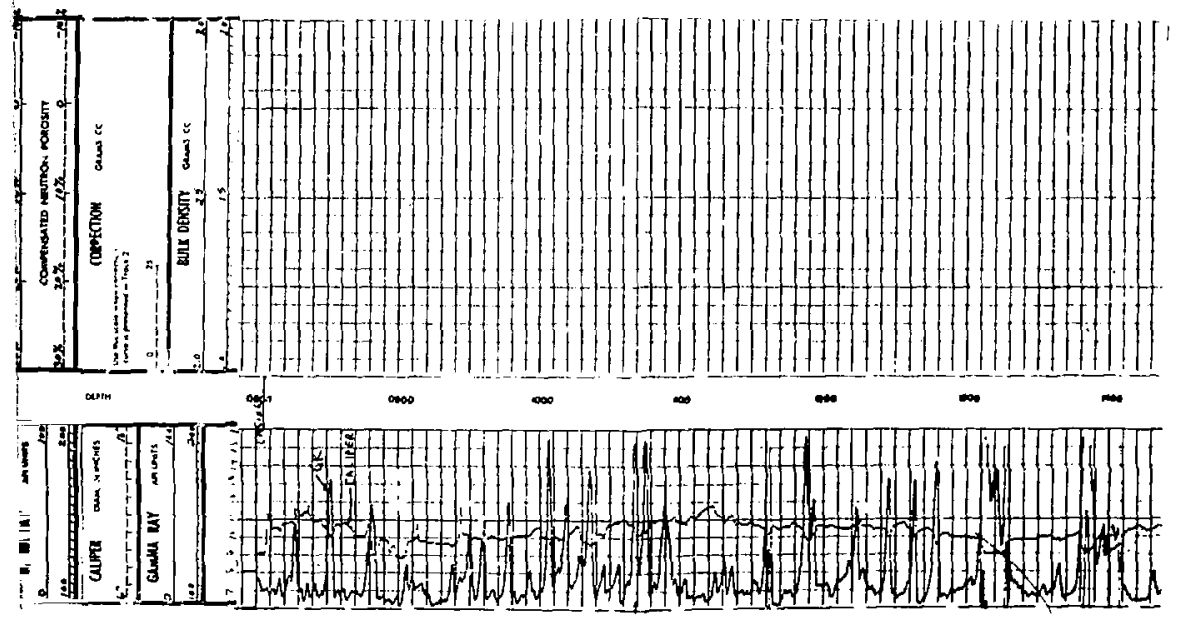

Log 


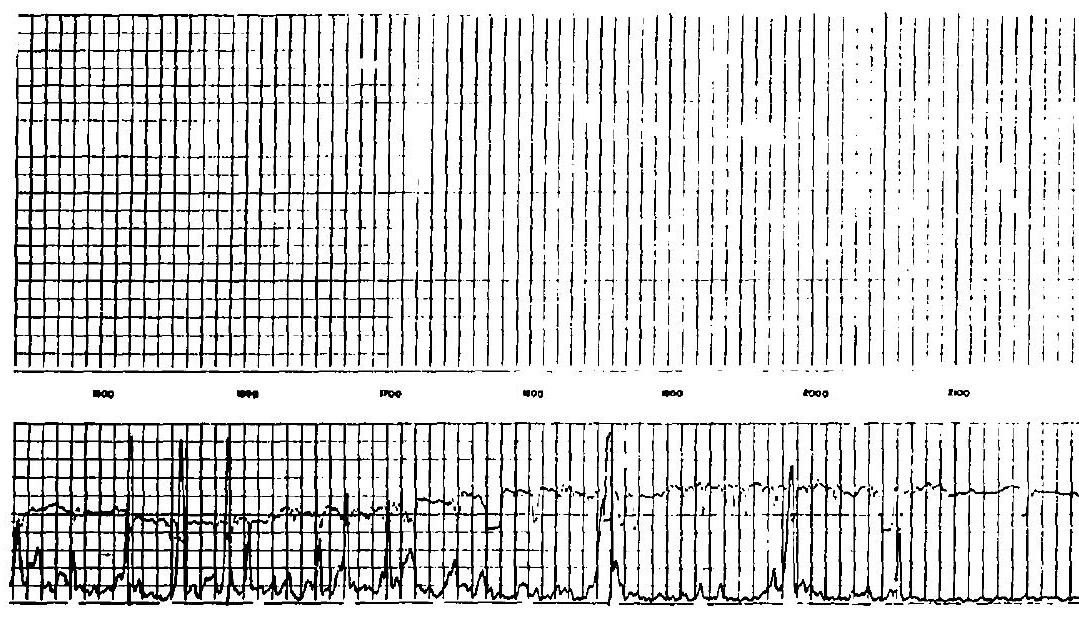

Figure 


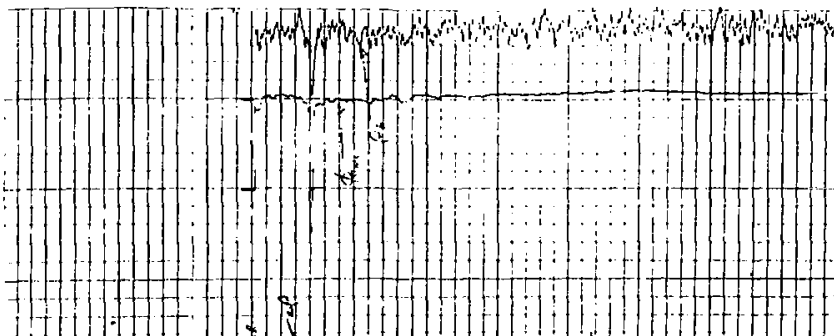
inilinini

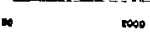

$\infty 0$
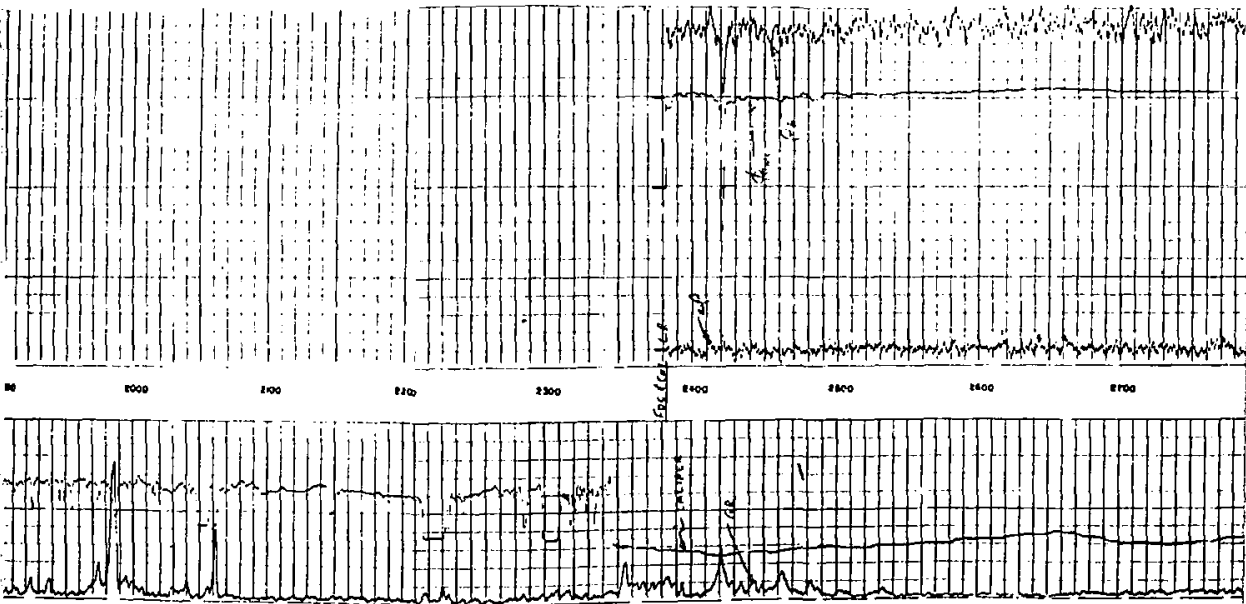

Figure 2. continued

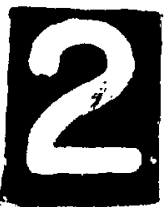



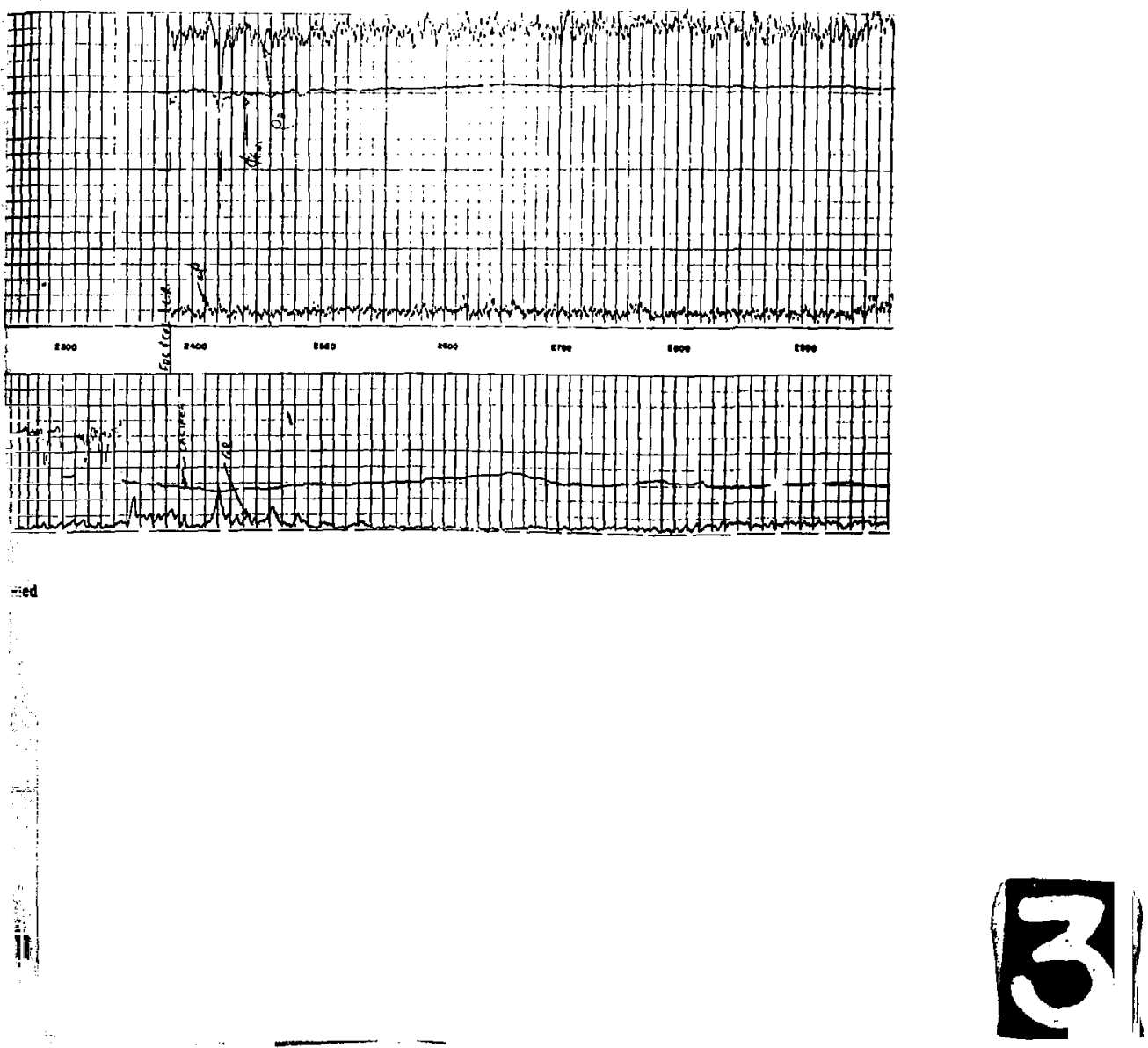


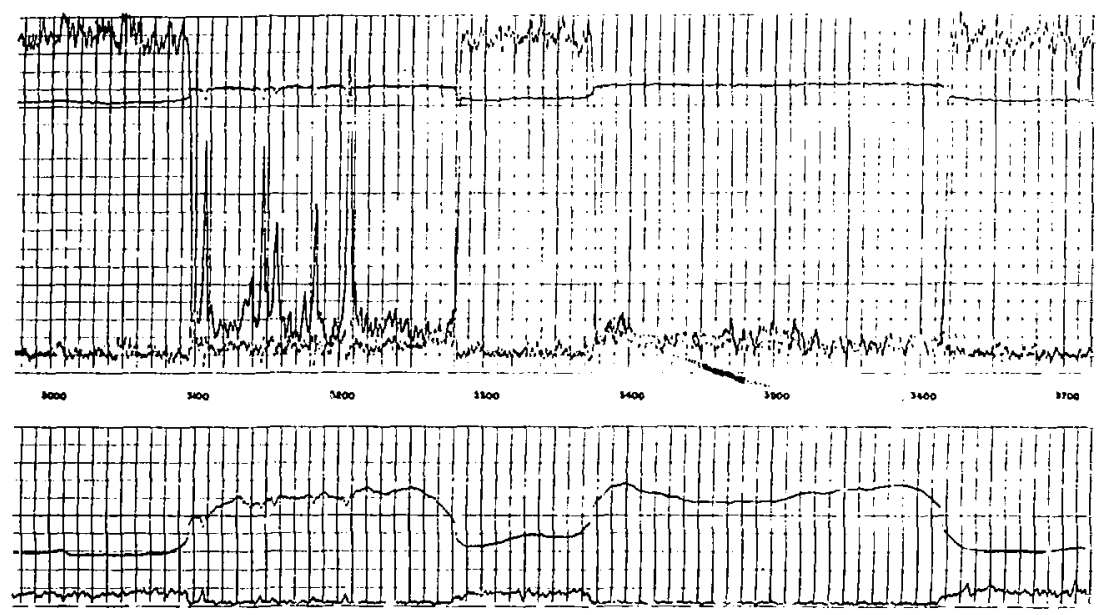

Figure 2. 


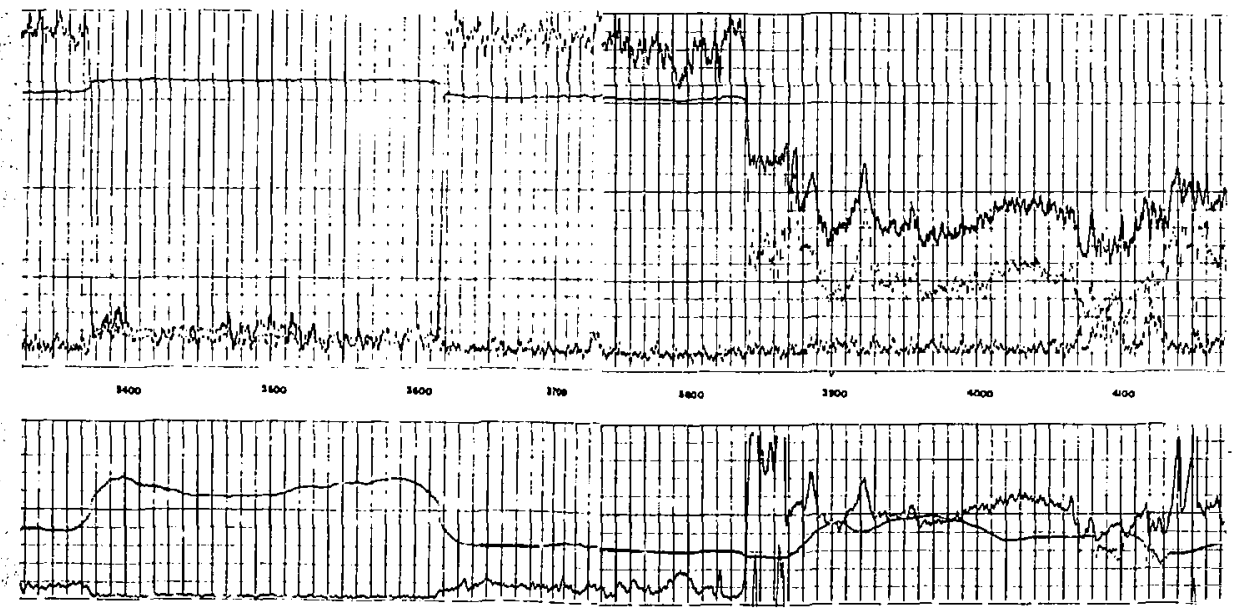

Figure 2, concluded

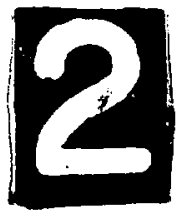




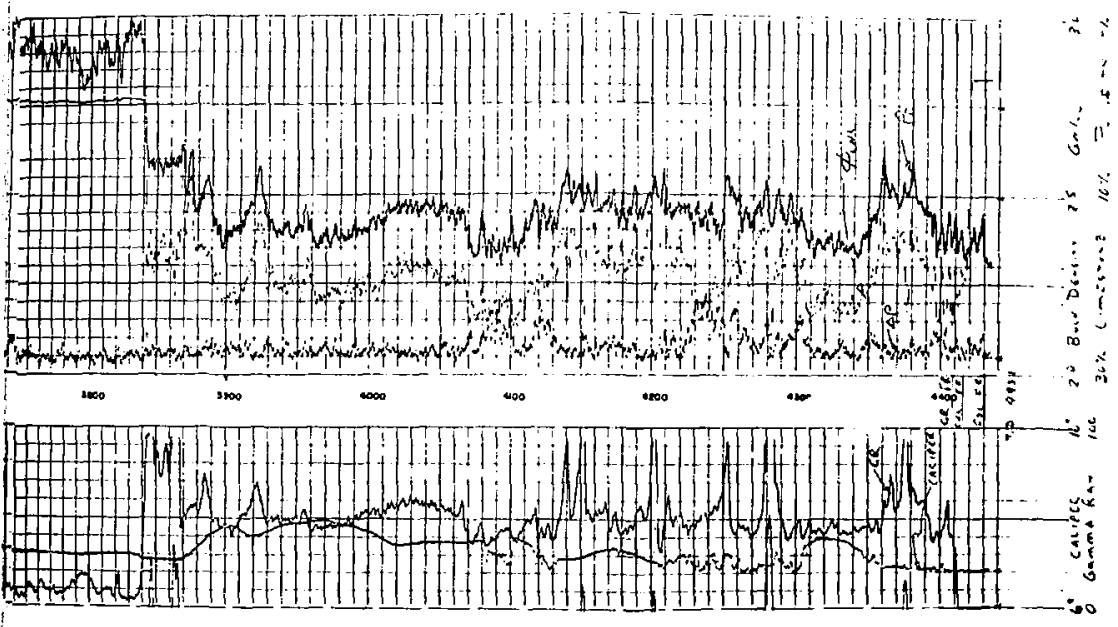

oncluded

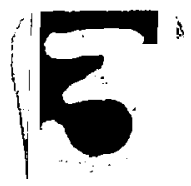


Table 1 lists the weights and pertinent data for each of the three different grout mixtures. The basic grout was 30\% Litepoz three (Inyash)/70\% Class C (SR) produced at the Maryneal plant of Lone Star Cement Company. It was supposed to have a zero $C_{3} A$ content and is recommended for the severe downhole environment in the Carlabad area. A fine granulated salt, which would dlssolve in the mix water was included in the first three plug mixtures which would be in contact with the salt formation. For plugg 2 and 3 , the salt content was $36 \%$ by weirht of the water which is approximately saturated. Plug i reduced the salt content to $30 \%$ so that the strength of the grout would be greater while still providing good bonding to the salt formation. Fresh $m$ ix water (no dissolved salt) was used for plug 4 inside casing for maximum strength and to prevent chloride corrosion of the steel. Additives fr $r$ plugs 1, 2, and 3 were calcium chloride $(2 \%)$, salt gel (attpulgite. $2 \%)$, dispersant $(0.1 \%)$ - all percents by weight of cement plus flytsh. Silica sand $5 \%$ ) was included in the first three plugs to improve strength characteristics and to reduce circulation loss to the formation. The additives for plug 4 were $2 \%$ Bentonite gei and a Iresh water turbulent inducer compound (friction reducer).

Dowell supplied the data in Table I. The grout slurries wer: testect at their Midland Laboratory for thickening time and strength gain in accordance with API ItPl0B "Testing Oil-Well Cements and Cement Additives" to simulate the downhole environment. The temperatures and confining pressures for each of the mixtures are listed in Table 1. The salt-saturated mixture for plugs 2 and 3 had the longest thickening time of $7 \mathrm{hr}, 45 \mathrm{~min}$. The unconfined compressive strengthe also ghow the effect of the salt in the mixtures. The plug 4 mixture hid the highegt strength at 72 -hr age even though the curing temperature was significantly lowtr. The omission of $6 \%$ of the salt tor plug 1 (30\% instead of approximately fully saturated $36 \%)$ gave approxima. a $50 \%$ strength increase at 72 hr for about the same temperature and confining pressure. These dati confirmed the assumptions that were made in selecting the grout mixture designs for each plug.

Dowell Laboratory also worked with samples of the drilling mud to determine the appropriate type and amount of chemical wash to precede the grout. The chemical wash removes the circulatable mud from the hole and the casing surface to improve bonding and to serve as a huffer between the mud and the cement so that mud gelation does not occur. Dowell recommended the following emounts of salt saturated CW-100 fuid loss control mud flush:

$\begin{array}{ll}\text { Plug 1 } & 2000 \text { gal, } 48 \text { bbl } \\ \text { Plugs 2, } 3 & 3500 \text { gal, } 93 \text { bbl } \\ \text { Plug 4 } & 1000 \text { gal, 24 bbl }\end{array}$


TABLE I

Grout Mixture Data

Cemient, Class $C(S R)$

Litepoz 3 (nyash)

Salt gel (Attapulgite)

Bentonite gel

Salt, D44

Silica sand, D44

Dispersant, D45

Dispersant, 465

Calcium chlorite (S1)

Water

Density

Density

Yir:id

Wiler content

Water/coment ratio

Waler/cement and flyash ratio

Thickening time"

Unconfined compressive stremgth

$24 \mathrm{hr}$
$+8 \mathrm{hr}$
$72 \mathrm{~h}$
Plug 1* Plugs 2, 3* Plug 1* 30\% 36\%

Units

Salt

Salt

lt) $/ \mathrm{ft}^{3}$

42.90

39.58

Water

$1 \mathrm{~b} / \mathrm{ft}^{3}$

14. 47

13.35

54. 83

lb $/ \mathrm{ft}^{3}$

1. 15

1.06

ib $/ \mathrm{ft}^{3}$

1b) $/ \mathrm{Ct}^{3}$

$-$

-

10. 77

14. 15

Ib $/ \mathrm{Ct}^{3}$

[b] $/ \mathrm{tt}^{3}$

3. 26

3. 01

0. 06

0.05

0.29

lb/ $\mathrm{ft}^{3}$

Lisit ${ }^{3}$

1.15

1.06

Lb) $/ \mathrm{Ct}^{3}$

36.6

39.3

36. 0

$1 \mathrm{~b} / \mathrm{ft}^{3}$

108.5

107. 0

112.2

lb/gal

14.5

14.3

$\mathrm{ft}^{3} /$ sack

I. 5

1. 7

6. 6

7. 13

0. 85

0. 9?

0.154

D. 74

15.0

1. 2

5.2

0. 65

0.49

hr:min

$4: 35$

$7: 45$

5:05

psi

712

$+2 C$

1210

1543

1032

1522

1868

1273

2080

- Plue 1 cured at $128^{\circ} \mathrm{F}, 2445$ psi

$=$

Plugs 2, 3 cured at $125^{\circ} \mathrm{F}, 2112 \mathrm{psi}$

Plug 4 cured at $80^{\circ} \mathrm{F}, 445 \mathrm{psi}$ 
All concerned agreed to the following operational procedures:

1. WES personntl will monitor the Iatcring of dry materials at the Dowell plant in Artesia and will obtain samples of all materials.

2. WES will take a sample of the blended material from the tiers on the bulk trucks at the sito.

3. After the 2-3/8 in. tubing is run in the hole and ready for cementing, the cement will be batch-mixed. WES will monitor the slurry density and take samples after the slurry is ready for pumping.

4. Saturated brine water and mud flush as drtermined above will precede the cement grout slurry.

5. The „. amping rate is to be 3 to $4 \mathrm{bbl} / \mathrm{min}$. Both the rate and pressure will be recorded.

6. Acter approximately two-thirds of the grout has baen pumped into the plug location. the tubing will be raised about one half the distarice of the plug drpth while maintaining at lrast 100 ft of grout atrove the bottom of the tubing.

7. Pumping will ie col'tnued until all of the grout has been pumped and displaced Irom the tubing or until uncontaminated grout appears at the surface. Where practicable, WES will obtain samples of both rontaminated and uncontaminated grout returns.

8. The $2-3 / 8$ in. tubing will be pulted,

9. The surface of the grout will be tagged after hardenirg before starting site operations for the next plug.

\section{Plugging Operations}

\section{Plug J}

Plugging operations began at the site on October 1. The batching of materials for plug 1 was completed at the Dowell plant in Artesia on September 30. The operation of the batch piant was inspected by Sandia and WES personnel, and the calibration dates of the scales were noted. Samples of each of the following materiale were obtained and later shipped to the WES Lab in Vickeburg for evaluation: 
Clase C (SIR) INCOR cement

Litepoz 3 (flyash)

At*apulgite (brine gel)

D44 salt

D45 salt cement diepersant

D65 turbulent flow additive

S1 calcium chloride

The Jry materials for plug 1 were weighed, blended, and loaded into the two tiers (tanks) of a bulk truck with dry materials for $207 \mathrm{ft}^{3}$ of grout slurry in each tier. The weighing operation was closely supervised, with the weight of each increment of material re orded by WES. After the hlending process was completed a sample was takcn for each tier. The batching operation was guccessful.

On-sile preparations for plug 1 began early on October 1 . The mixer was a twin tank. paddle mixing aystem with about $40 \mathrm{bbl}, 224 \mathrm{ft}^{3}$ eapacity in each lank. Some dirficulty was encountered during the hookup and preliminary checkout of the system. Repairs and adjustments were satiafactorily completed by 11:00 a. m. Mixing of the grout then began with bott: the mix water and ambient air temperatures of $60^{\circ} \mathrm{F}$. A sample of the dry material was taken froun each tier of the bulk truck to check for any evidence of segregation during transport from the batch plant to the site.

With most of the rresh mix water in the tank, the dry materials were blown from the tiers on the bulk truck into the mixing tank by 10 to 15 psi air pressure. The slurry density was frequen $y$ checked by Dowell and WES after all the dry material had been added. The initial density was $14.9 \mathrm{lb} / \mathrm{gal}$ and was lowered to $14.7 \mathrm{lb} / \mathrm{gal}$ by the addition of water. At about $11: 10$ a. $m$. the slurry was pumpable, and the deciaion was made to use the grout slurry at this fensity ratrer than to add water to lower the mixture to the design density of $14.5 \mathrm{lb} /$ gal. The second batch was mixed while batch 1 was being agitated in the tank. The initial slurry density was 15. $1 \mathrm{lb} / \mathrm{gal}$ and cosld not be lowered below $14.9 \mathrm{lb} / \mathrm{gal}$ within the capacity of the mixing tank. This slurry was pumpable. and the decision was reached to pump batch number two into the hole first (thus becoming the grout at the top of the plug). The higher slurry density generally results in a higher strength.

The bottom of the tubing in the hole was just above the hole bottom $4431 \mathrm{ft}$ deep. Sturting ut 11:45 a.m. Dowell pimped $10 \mathrm{bbl}$ of brine water, $48 \mathrm{bbl}$ of chemical rnud flush and another 10 sbl of brine water at a pumping rate of $4 \mathrm{bbl} / \mathrm{min}$. The grout glurry was then mmped at a rate of about $3 \mathrm{bbl} / \mathrm{min}$ at a ine pressure of 1000 to $1250 \mathrm{psi}$. The pumping of all $414 \mathrm{ft}^{3}$ was finished by aboul 12:30 p. m. without any difficulty. The temperature of the grout olurry was $98^{\circ} \mathrm{F}$ at the beginning and $103^{\circ} \mathrm{F}$ at the completion of pumping. 
WES cast cylinder specimene for obeervation and later shipment to the WES Laboratory for testing and evaluation. The cylinders were sealed and stored at the site and protected from the sun. At about 7-hr age, the samples from batch 1 were obscrved to have passed initial set, but not final set and had about the normal 1 to $2 \%$ bleed water at the surface. The samples from the batch 2 were hard to the touch (after final set), had no bleed water on the surface, and were warm from internal heat of hydration of the cement. These observations confirmed the higher fluid density (and lower water/cement ratio of batch 2) which resulted in a [agter setting and hydration process. The ambient air temperature at the time of this observation was $90^{\circ} \mathrm{F}$, and the peak air temperature had reached about $98^{\circ} \mathrm{F}$ during the afternoon.

The tubing had been removed from the hole after the comletion of puniping, and the cement plug was allowed to harden for about $48 \mathrm{hr}$. The top of the hard material was tagged with the core barrel at a depth of $\mathbf{3 5 5 6} \mathbf{~ [ t . ~ T h i s ~ i n d i c a t e d ~ t h a t ~ l i t t l e , ~ i f ~ a n y , ~ g r o u t ~ w a s ~ l o s t ~ t o ~ t h e ~ f o r m a t i o n . ~}$ Th: $30 \%$ excess above hole size calculation filled an additional $25 \%$ extra hole depth. Also the higher than design density of the grout reduced the available grout volume by about $2 \%$, and some grout was left in the mixing tanks.

Coring operations began at toon on October 3 (48-tre age of the grout) and were completed at midinght. A 50-ft core barrel with a core diameter of approximately 4 in, was used, Core 1 was Jrilled through the $39-\mathrm{ft}$ interval (rom 3550 to $3595 \mathrm{ft}$ with about $10 \mathrm{ft}$ of recovered core mostly short pieces. Core 2 way drilled througt the 28 -ft interval from 3595 to 3623 ft with about 20 it of recovered core with mos: Fieces about $10 \mathrm{in}$, or longer. Core 3 was drilled through the $50-\mathrm{ft}$ Irterval of 3623 to $3673 \mathrm{It}$ with about 28 It of r. covered core, with most pieces 0 in. or' longer.

From the Dowell Laboratory data, the strength of the cement grout at 48 -hr age should have been about 1543 psi for unzontaminated grout cured under the pressure of the column of drilling mud in the hole and at $128^{\circ} \mathrm{F}$ (Table I). The sore barrel was stuck at the end of each coring cycle which may have contributed to grinding $d$ lose of sonie of the core. The core was immediately placed and sealed in plastic containers, prevent moisture loss during storage and shipment. The core pieces and surface cast samplus were shipsed to the WES Laboratory for testing and evaluation. Samples were aloo given to Dowell for tegting in their laboratory at Tulsa.

\section{Plug 2}

The materlais for plug 2 were batched and blended at the Artesia Dowell plant on Monday, October 1, under WES supervision. Because of the higher density for the cement slurry for plug 1, the bulk trucke were carefully inspected before loading. The lowe. portion of earh of the tiers on each of the trucks was found to contain some cement. The norrial cleaning operation at the yard appa rently did not completely remove a small amount of the dry cement. All bulk trucks for this and subsequent plugs were carefully cleaned of all dry material before loading.

W $\overrightarrow{E S}$ again supervised and recorded the weights of each material during the batching operations. Samples of the dry mixture from each of the four tiers were taken after blending and 
loading before the trucke left the plant for the site. Three of the batches were $282 \mathrm{ft}^{3}$, and the fourth batch was $266 \mathrm{ft}^{3}$ for the total plug volume of $1112 \mathrm{ft}^{3}$ when mixed to the design slurr:" weight or $14.3 \mathrm{lb} / \mathrm{gal}$.

On-site operations began early in the morning of Dctober 3. Because of the opera:ional problems with. "Ightning" batch mlxers used on plug 1, the mixing equipment was changed for this and subse. If $n$ plugs. The grout slurry was mixed in the "tornado" mixer on the pump truck and pumped into a large horizontal cylinder tank with agitating blades. The tank capacity was $240 \mathrm{bbl}, 1344 \mathrm{ft}^{3}$, e nough for all of the slurry for each of the rem ining plugs. A sample of the blended dry material from each tier was taken before mixing. Mixing started at 8: 10 a. m. and was completed at 9:55 a.m. The uniform tluid density at the completion of mixing was 14.6 lb/gal. This was slightly above the design density $14.3 \mathrm{lb} / g a l$ and was pumpable. The weather was cool and raining during the grouting opera*ions. Mix water tempe:ature was $72^{\circ} \mathrm{E}$, and the grout temperature was $88^{\circ} \mathrm{F}$.

The tubing extended lown to the top of the hardened grout (nfter coring) at a depth of 3673 ft. Pumping operations started at about $9: 55 \mathrm{a} . \mathrm{m}$. The $10 \mathrm{bbl}$ of brine water was followed by $84 \mathrm{btl}$ of chemical mud flush, and another 10 blsl of brint water preceeded the grout. The brint and luud flush was pumped at a rate of $4 \mathrm{hbl} / \mathrm{min}$ and a line pressure of about 1000 psi. The grout slurry was puinped at an average rate of about $3.5 \mathrm{bbl} / \mathrm{m}$, n and a line pressure of about 2000 psi for the first two-thirds of the plu $u_{b}$ volume. Pumplng was stopped, and the tubing bottom was raised to $2953 \mathrm{ft}$. This depth should have placed the bottom of the lubing at least 100 ft below the grout/drilling mud in the hole. The remaining grout slurry was pumped at a rate of 3.6 $\mathrm{bbl} / \mathrm{min}$ and a line pressure of 500 to $1100 \mathrm{psi}$. The grout slurry was displaced from the tubing. and the tubing bottom was raised to $2300 \mathrm{ft}$. Reversing out the top portion of the grout slurry was attempted by pumping drilling mud down the tubing. No grout was observed at the surface. The grouting operations were completed at $11: 20$ a. $\mathrm{m}$.

The surface of the grout was later tagged at $2335 \mathrm{ft}$ after a $12-\mathrm{hr}$ wait to allow the cement to harden. During the pumping, the return of mud to the pit was noticeably lefs for a portion of the time, and geveral reductions of line plessure were noted on the pressure recorder. Approximately $30 \%$ of the grout slurry was lost to the formation. The increase in slurry weight resulted in a $2 \%$ volume decrease. After completing the pumping, approximately $10 \mathrm{bbl}, 56 \mathrm{ft}$ or $5 \%$ of the total grout slurry in the agitating tank was below the suction line to the pump truck and had to be lushed out during rleanup. This loss in slursy volume of $7 \%$ was about equal to the reduction in plug length (and approximate volume) of $6 \%$. Therefore, the planned $30 \%$ excess was not available to reverse out and clean off the top of the plug.

WES cast eamples of the grout slurry during the pumping of the plug. The mixture appeared to be uniform, and all samples had hardened normally by the time that they were examined about $18 \mathrm{hr}$ later. The normal $1 \%$ to $2 \%$ bleed was shown by the top surface of the hardened grout in each cylinder. 


\section{Plug 3}

The matertals for plug 3 were batched and blended du: ing the late alternoon and evening of October 4 under WES supervision. Five tiers were loaded on a total of three batch trucks--four batches of $282 \mathrm{rt}^{3}$ and one batch of $201 \mathrm{ft}^{3}$. Samples of the dry mixture from each of the five tiers were taken after blending and scading.

On-site operations began the morning of October 5 . The mixing and agitating tank equipment were the same as that used for plug 2. The mixing of the grout slurry started at 11:50 a. $\mathrm{m}$. and was completed at $12: 55 \mathrm{p}, \mathrm{m}$. Ambient air temperature was $65^{\circ} \mathrm{F}$, mix-water temperature was $69^{\circ} \mathrm{F}$, and :. ititial grout temperature into the tank was $84^{\circ} \mathrm{F}$. After mixing $1329 \mathrm{ft}^{3}, 237 \mathrm{bbls}$ the slurry temperature was $89^{\circ} \mathrm{F}$ and the dersity was $14.7 \mathrm{lb} / \mathrm{gal}$.

Pumping started at 12:45 p.m. with the tubing about Il ft abote the hardened surface of plug 2 at $2324 \mathrm{ft}$. The $10 \mathrm{bbl}$ of brine water, 84 bbl of chemical mud flush, and 10 hbl of brinc water were pumped downhole beginning about $12: 45 \mathrm{p} . \mathrm{m}$. at a rate of $4 \mathrm{bbl} / \mathrm{min}$ and completed at about 1:05 p. m. The first 155 bbl of grout slurry was pumped dowinhole at a rate of about 3.5 $\mathrm{bbl} / \mathrm{min}$ and at a pres qure of 500 to $1000 \mathrm{psi}$ The tubing was then pulled to $162 \mathrm{ft}$, and the remaining $82 \mathrm{bbl}$ of grout was pumped at the same rate ard with a line pressure of 300 to $500 \mathrm{psi}$. The grout was displaced from the tubing by pumping dr.lling mud down the tubing. The tubing was then raised to the bottom of the casing at $805 \mathrm{ft}$. The graut above that level was reversecirculated out of the holo by pumping the drilling mud down the annulus and forcing the grout up the tubing. Samples of the grout return were obtained during the pumping of approximately 40 bbl, $224 \mathrm{ft}^{3}$ of cement $\mathrm{g}_{1}$ ut and drilting mud. Pumping operatione were completed at $2: 40 \mathrm{p} . \mathrm{m}$. About 8 hr later the hardened top of the grout was tagged at $826 \mathrm{ft}$.

WES cast the usual cylinder samples of grout taken from the agitating tank during the pumping of the plug. The samples exhibited a normal stiffening at about 10-hr age. Five of the $\theta$ ix return sample specimens appeared to be relatively uncontaminated with drilling mud. The last specimen appared to be mostly drilling mud with about $25 \%$ cement grout which had settled to the bottorn.

Plug 4

Batching of dry materials for plug 4 was supervised by WES during the evening of October 5 . One bulk truck was loaded with one tier containing $212 \mathrm{ft}^{3}$ and $204 \mathrm{ft}^{3}$. This provided about $20 \%$ above the calculated volume inside the casing to the surface.

Mixing truck and agitating tank remained in place because of the short time between cleanup and preparing for the next plug at $10 \mathrm{p} . \mathrm{m}$. Mixing of the grout began at 12:35 p. m, Ambient air temperature was $50^{\circ} \mathrm{F}$ and the mix $\%$ ater temperature was $80^{\circ} \mathrm{F}$. After mixing, the grout temperature was $90^{\circ} \mathrm{F}$ and the dengity was $14.9 \mathrm{lb} /$ gal - slightly under the degign density of 15. $0 \mathrm{lb} / \mathrm{gal}$. The bottom of the tubing was at $8: 6 \mathrm{ft}$. Pumping of $10 \mathrm{bbl}$ of brine water, $24 \mathrm{bbl}$ of chemical mud flush. and $10 \mathrm{bbl}$ of water ahead of the cement grout began at 12:10 a. $\mathrm{m}$. On October 6 at a rate of about $4 \mathrm{bbl} / \mathrm{min}$ and a preseure of $300 \mathrm{psi}$. The firgt $10 \mathrm{bbl}$ of grout was 
pumped Jownhole at a rate of $3 \mathrm{bbl} / \mathrm{min}$ and the same pressure of 300 psi. Two joints of tubing were removed which raied the tubing to 760 ft for pumping the remainder of the plug. The final $64 \mathrm{bbl}$ of grout was pumped at the rate of $3 \mathrm{bbl} / \mathrm{min}$ and the same pressure.

The uncontaminated gro't did appear at the top of the casing. No samples of this return were taken becauge the grout ran to the hottom of the pit with drilling mud above. WES did cast the usual samples of grout taken from the agitating tank during pumping. Grouting operations were completed at 1 a.m.

The next day the level of grout had subsided atout $16 \mathrm{ft}$ below the top of the casing. This space was filled with a neat cument slurrs.

General Comments and Conclusions

The samples remained id the site for at least $24 \mathrm{hr}$ and ware the st moved to the Silndia office in carlsbad. Pesting of the coru and surface samplus from plug 1 was intundes to begin as soon as possible at the WhS laborutory in Vicksburg. Mississippi. Four cylinders und four boxes of core were shipped by air al b-elays age. The remainder of all samples and coro wore shipped by surface after the saniples from pling it iad reached 7 -days age.

For plug I little, if any, Grout was lost to the formation since the $30^{\circ}$ axcess frout filled about $25 \%$ extra hole, Also, the kigher-that-design density reduced the available volume by about 2\%. Most of the 30\% cxcess grout for plug 2 was probably lost to the formation. The lop of the plug 1 grout after coring was still 57 ft above the level used for estimating the volume and thereby reduced the planned volume by $4 \%$, For plug 3, probably little grout was lost to the Corr.ing. The amount circulated out and the extra depth of hole to he fllled just about equaled tlic . $0 \%$ exces. The available excess grout for plug + was reduced to about $10 \%$ because of the outlet pipe location for the agitating tank which caused 6 to 10 blol to rcmain in the tank. This was more severe for plug 4 because of the smaller plug volume. This feature pointed out another of the details which are important in the planning for a plugging operation.

The quality control procedures were adequate to provide a uniform cement slurry at the job site for pumping downhole into the plug locations. The cores recovered from plug 1 after only 24-hr curing showed that the grout in place hardened and gained strength similarly to the labora. tory specimens tested under the teinperature of $128^{\circ} \mathrm{F}$ and 2445 psi. There was no evidence of mud contamination in the hardened grout below the first core barrel depth of $50 \mathrm{ft}$. The surface cast specimens for all plug mixtures hardened through initial and final set within 12 hr as expected for the ambient air temperature conditions. 
The operations at the batch plant were sampled and recorded to provide a data base for future borehole plugging operations. The data from the samples will be reported in subsequent reports as a part of the long term development and durability studies for the materials development and evaluation program.

References

1. Gulick, Z: W., "Borthold Plugging - Materials Development Program", SANDiB-0715, June 1978 